DIW BERLIN

Discussion Papers
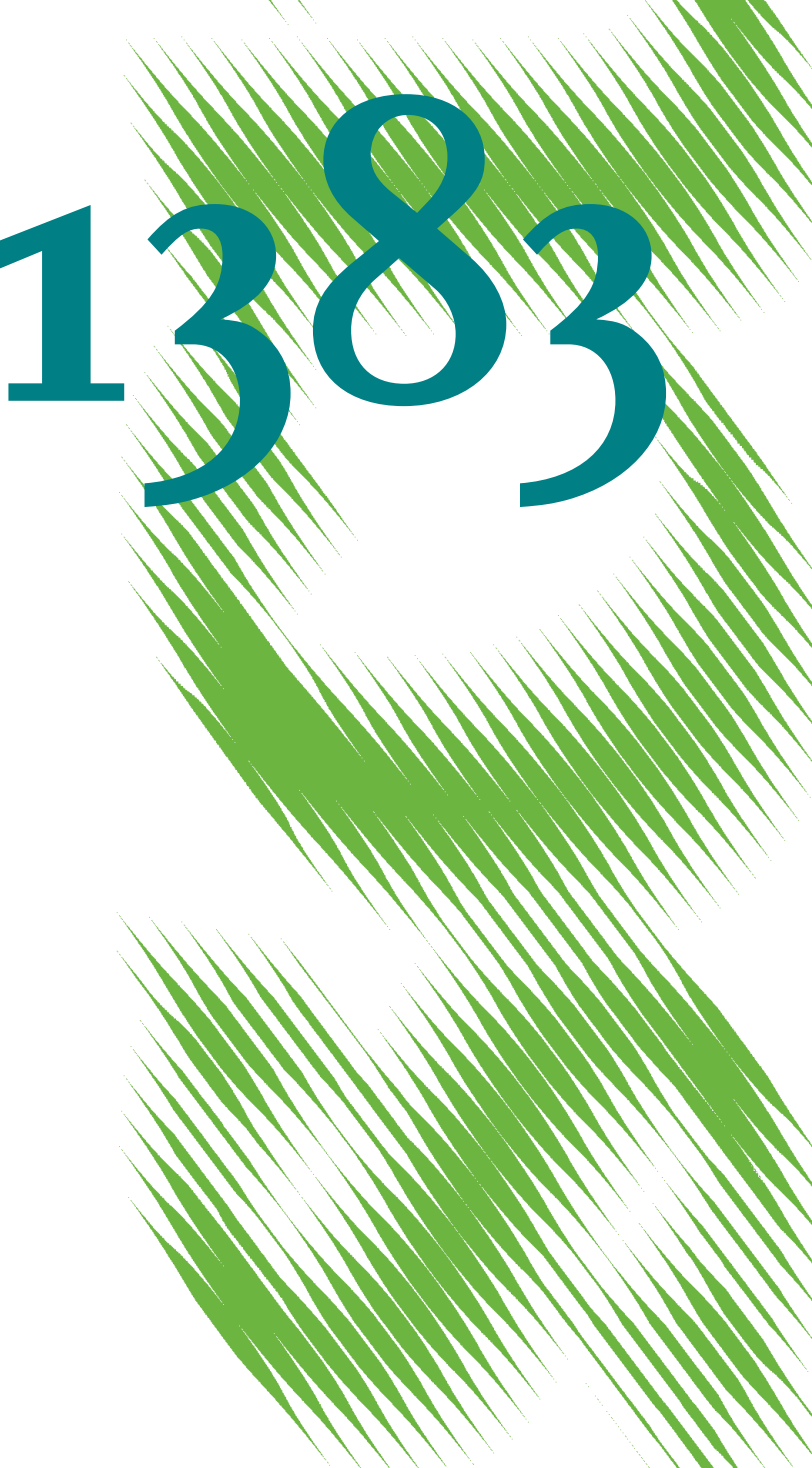

All Quiet on the Eastern Front? Disruption Scenarios of Russian Natural Gas Supply to Europe 
Opinions expressed in this paper are those of the author(s) and do not necessarily reflect views of the institute.

IMPRESSUM

(C) DIW Berlin, 2014

DIW Berlin

German Institute for Economic Research

Mohrenstr. 58

10117 Berlin

Tel. $+49(30) 89789-0$

Fax +49 (30) $89789-200$

http://www.diw.de

ISSN print edition $1433-0210$

ISSN electronic edition 1619-4535

Papers can be downloaded free of charge from the DIW Berlin website:

http://www.diw.de/discussionpapers

Discussion Papers of DIW Berlin are indexed in RePEc and SSRN:

http://ideas.repec.org/s/diw/diwwpp.html

http://www.ssrn.com/link/DIW-Berlin-German-Inst-Econ-Res.html 


\title{
All Quiet on the Eastern Front? Disruption Scenarios of Russian Natural Gas Supply to Europe
}

\author{
Philipp M. Richter ${ }^{a}$ and Franziska Holz
}

May 26, 2014

\begin{abstract}
The Russian-Ukrainian crisis has revitalized the European concerns of supply disruptions of natural gas as experienced in 2006 and 2009. However, the European supply situation, regulation and infrastructure have changed since: imports are more diversified, EU member states better connected and a common regulation on the security of supply has been introduced. Nevertheless, several East European countries are highly dependent on Russian natural gas. This paper investigates different Russian natural gas export disruptions scenarios and analyses short- and long-term reactions to ensure a sufficient supply of natural gas within Europe. We use the Global Gas Model (GGM), a large-scale mixed complementarity representation of the natural gas sector with a high-level of technical granularity with respect to storage and transportation infrastructure. We find that most of the EU member states are not severely affected by a complete drop out of Russian exports. Removing infrastructure bottlenecks within the EU should still be prioritized in order to secure a sufficient natural gas supply for all EU member states.
\end{abstract}

Keywords: natural gas trade, Russia, Europe, security of supply, infrastructure investment, equilibrium modelling

JEL Codes: Q34, Q37, Q41, C61, L95

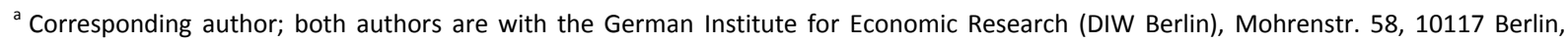
Germany. Tel.: +49 3089789 432. E-mail: prichter@diw.de. This work is carried out within the research project "RESOURCES: International Energy Resource Markets under Climate Constraints - Strategic Behavior and Carbon Leakage in Coal, Oil, and Natural Gas Markets," funded by the German Ministry of Education and Research. It evolved from a study carried out for the European Parliament, The Greens European Free Alliance. We thank Hanna Brauers, Ruud Egging, Pavel Evtuhov, Christian von Hirschhausen, Daniel Huppmann, Claudia Kemfert and Kirsten Westphal for very helpful feedback. The usual disclaimer applies.
} 


\section{$1 \quad$ Introduction}

Tensions between the Russian Federation and Ukraine have revitalized European concerns about the security of natural gas supply in the spring of 2014. Civil unrest in Ukraine, disputes with Gazprom over natural gas prices and transit fees have led to the fear of an interrupted Russian natural gas supply to Ukraine and via Ukrainian transit pipelines to the EU. At first sight, the dispute over natural gas prices and potential interruptions of supply are comparable to 2006 and 2009, although the situation seems more severe with a looming war between Russia and Ukraine.

However, since 2009 both the global and the European natural gas sectors have significantly changed:

1. Since the inauguration of the Nord Stream pipeline in late 2011, Russian exports of natural gas via the Ukraine have further diminished from 65\% in 2010 to only about $50 \%$ of total Russian exports to Europe (IEA, 2014).

2. The EU has reduced the share of Russian natural gas in total imports following a longterm trend: While in 2001, the share of Russian natural gas in total imports of the EU28 has been above 50\%, it reached $37 \%$ in 2012 (based on IEA, 2013).

3. The EU regulation $994 / 2010$ (EU, 2010) has been introduced to harmonize national emergency plans. Many EU interconnectors have been expanded and now allow for reverse flows.

4. The import capacity of Liquefied Natural Gas (LNG) in the EU has been expanded by $15 \%$ between 2009 and today; an increase of more than $20 \mathrm{bcm}$ to more than $180 \mathrm{bcm}$ of physical import potential (cf. GIIGNL, 2010, 2013). LNG imports could still be increased since utilization rates are low with only about $30 \%$ on average in the EU in 2012 (IEA, 2013).

5. While US natural gas imports have been more than 50\% lower in 2013 than in 2009, production has increased by almost $20 \%$ due to a boom in the extraction of shale gas (EIA, 2014b). In particular, LNG imports are much lower than previously expected and current projections expect the USA to become a net exporter of natural gas as of 2020 (EIA, 2014a; Richter, 2013).

6. On the other hand, Japan attracts more LNG imports to compensate for the (at least temporary) phase-out of nuclear power in the aftermath of the Fukushima Daiichi nu- 
clear incident (cf. Hayashi and Hughes, 2013). Compared to a ten year linear trend until 2010, Japanese LNG imports (IEA, 2013) have been about 20 bcm higher in 2012.

7. In 2012, natural gas consumption in the EU has been lower by $4 \%$ than in 2009 (IEA, 2013). This is due to the economic crisis and low $\mathrm{CO}_{2}$ prices. The mild winter 2013/2014 has left storage facilities filled above-average.

Behrens and Wieczorkiewicz (2014) see the EU better prepared for any disruption of Russian supply and highlight the dependence of Russia on its main customer. Although the Asian market is an attractive alternative with good prospects (Paltsev, 2014), in the short-run actual trade flows are limited due to a lack of production and transportation infrastructure. Both LNG export capacities and pipeline infrastructure toward Asian consumption regions have yet to be constructed in large scale.

Despite all progress, the disruption of Russian natural gas exports to Europe may have severe consequences, in particular for several East European countries. The focus of this paper consequently lies on short- and long-term adjustment possibilities. We investigate the European natural gas market position, focus on alternative natural gas suppliers, and analyse the expansion of existing infrastructure in order to ensure the secure supply of natural gas.

For this purpose, we use the Global Gas Model (GGM; Egging, 2013; Holz et al. 2013), a partial equilibrium model of the natural gas sector with a pronounced focus on natural gas trade and infrastructure. Notably, the current EU natural gas infrastructure is taken into account, regarding its connection to external suppliers as well as the distribution network within the EU. Cross-border pipelines and global infrastructure to trade LNG are included in the model. We compare three Russian natural gas supply disruption scenarios to a Base Case projection: two of a short-term nature, affecting, respectively, the Ukrainian supply and transit, and all Russian export pipelines to Europe, as well as one long-lasting disruption of Russian natural gas supply to the European customers. Although unlikely, these counterfactuals serve to identify bottlenecks within the European natural gas infrastructure and highlight possibilities and necessary expenses to diversify the European supply of natural gas.

The role of Russian natural gas supplies to Europe and in particular the importance of the individual transit routes has been discussed since the 1990s when Russia started to diversify from its traditional export route via Ukraine by constructing the so-called Yamal-Europe pipeline via Belarus (Figure 1). Hirschhausen et al. (2005), for example, show that Yamal- 
Europe helped Russia to enforce cooperative behaviour by the transit country Ukraine. Similarly, Hubert and Ikonnikova (2011) discussed the bargaining threat of the direct pipeline link between Russia and Germany (Nord Stream) on the transit countries Ukraine and Belarus. However, the construction of the Nord Stream pipeline indicates that Russia did not perceive the threat to divert its exports as credible enough to discipline Ukraine and Belarus.

In addition, several numerical models of European and global natural gas markets can be found in the recent literature. Depending on the model setup, they may yield quite different results of disruption scenarios. In particular, one has to distinguish optimization models with a cost-minimization focus from equilibrium models with market power considerations of strategic players. While the former can hardly represent the real-world trade flows with their diverse suppliers, the latter may yield higher price levels than actually observed.

Lochner (2011) and Lochner and Dieckhöhner (2012) use the optimization model TIGER to investigate the impact of Russian or North African supply disruptions, respectively. Lochner (2011) emphasizes the role of reverse flows and storage during a short-term disruption of Russian supplies to Eastern Europe. Lochner and Dieckhöhner (2012) show that Italian consumers can to a large extent divert to additional LNG imports if North African supplies are interrupted.

Using an equilibrium model, Holz (2007) shows that Russia does not to have an incentive to behave strategically in a European market where several alternative suppliers are present. Russia has lower profits as a Cournot player than as a perfectly competitive player. Using the European Gas Model, Egging et al. (2008) analyse i.a. a disruption of the Ukrainian transit and calculate that the European natural gas price increases by almost $20 \%$ on average and that Hungary is the most hit country. Huppmann et al. (2011) present a more comprehensive disruption scenario of Russian supplies with the World Gas Model, similar to our scenario definitions. Huppmann et al. (2011) obtain a 40\% price increase in Europe in 2015, in line with a reduction of consumption by more than $10 \%$. In the long run, in a rather unconstrained model run, Russian supplies would be replaced by considerable LNG imports to Europe which require significant LNG import capacity investments. Russia would earn $40 \%$ less profits in this scenario than in the Base Case due to the smaller sales volumes.

Compared to this earlier literature, we use an updated and more refined data set, in particular on the European infrastructure. Similar to Egging et al. (2008), our results show that a disruption of Russian exports to Ukraine and via the Ukrainian transit severely affects some 
East European countries, primarily Ukraine. On average, the EU is only affected by slightly higher prices, though. A complete disruption, as in Huppmann et al. (2011), would affect all EU countries with an average price increase of more than $20 \%$ in the first year of the shock with large regional deviations across European countries: East European countries are affected far more severely. The change of the import structure is dominated by a stronger reliance on LNG imports. Results indicate that the EU LNG import capacity is insufficiently connected to the broader market.

In case of a long lasting interruption of Russian supply, more investments in the transportation infrastructure are necessary to diversify the EU imports and balance the internal market than in the Base Case. These include the connection of the Iberian peninsula and Italy to Central Europe to distribute the large import potentials of both countries from North Africa and the global LNG market. Pipeline expansions to reach the Baltics and Finland from Poland are advisable, as well as investments in the pipeline network in the Southern Corridor to bring natural gas from the Caspian region and the Middle East via Turkey to those countries, which are most affected of a Russian supply disruption.

The remainder of this paper is organised as follows. Section 2 provides a description of the GGM and presents its underlying data set with a specific focus on the European natural gas import infrastructure. In Section 3 we discuss our model results and offer interpretations. Section 4 concludes and highlights policy implications of the conducted analysis.

\section{$2 \quad$ Methods}

We make use of the Global Gas Model (GGM) to simulate future patterns of natural gas production, consumption and trade, and to analyse, in particular, counterfactual scenarios around supply disruptions of Russian natural gas to Europe.

\subsection{Model and data description}

The GGM is a partial equilibrium model of the global natural gas sector. The basis of the GGM is a stylized representation of market entities along the entire natural gas value chain, i.e. producers, traders, transmission and storage system operators (TSO and SSO), as well as final consumers. These agents are characterized by optimizing behaviour under operational and technical constraints, such as transportation and storage capacity restrictions. 
The model features seasonality, market power of selected traders, and endogenously determined investments in infrastructure. Players are assumed to behave under full information and perfect foresight; the results are thus to be interpreted as long-term costefficient equilibria in the presence of market power. It is abstracted from institutional friction, such as long-term contracts or oil-price linking. Hence, adjustments in international trade of natural gas are facilitated in the model relative to the real world. ${ }^{1}$

The GGM is set up as mixed complementarity problem (MCP; cf. Facchinei and Pang 2003), numerically applied and solved using the PATH solver with the software GAMS (Ferris and Munson, 2000). Equilibria are calculated in 5 years steps starting in 2010 and reported until 2040.

The GGM data set includes 98 countries represented by 119 nodes. ${ }^{2}$ Each node is characterised by current and projected consumption and production levels, prices, production capacities and costs, as well as capacities of the transmission and storage system. The data originate from various and mainly public sources. For instance, cross-border capacities of pipelines toward and within Europe are provided by ENTSO-G (2013a), ${ }^{3}$ information for worldwide LNG infrastructure is given by GIIGNL $(2011,2012,2013)$ and storage capacities by GIE (2011, 2013). Furthermore, we make use of IEA and EIA publications, data from national statistics offices, and company reports.

Capacities of pipelines, LNG and storage facilities for the model periods 2015 and 2020 are determined by exogenously included capacities, i.e. infrastructure that is available today and that is currently under construction, and by endogenously determined expansions in the model period 2010. Expansions in later model periods are solely determined by endogenous decisions. Figure 1 shows the European infrastructure to import natural gas from external suppliers, both through LNG terminals and pipelines. Pipeline capacities are given in the figure, while Table 1 provides information on capacities of operating LNG regasification ter-

\footnotetext{
${ }^{1}$ A more thorough model description including the mathematical formulation can be found in Egging (2013). See Holz et al. (2013b) for a model application.

2 The GGM database includes 23 EU member states in 21 nodes (Lithuania, Latvia and Estonia are aggregated in the region "BALT"). Not included EU member states are Cyprus, Luxembourg, Malta, Sweden and Slovenia.

${ }^{3}$ Note that entry/exit capacities given by ENTSO-G are not necessarily equal to physical restrictions but rather represent "capacity simulations performed by the respective TSOs" (ENTSO-G, 2013b, p. 29). Due to lack of an alternative comprehensive data set, we implement the ENTSO-G data as initial capacities.
} 
minals in the EU as of today, and as included in the GGM simulation runs for the period 2015.

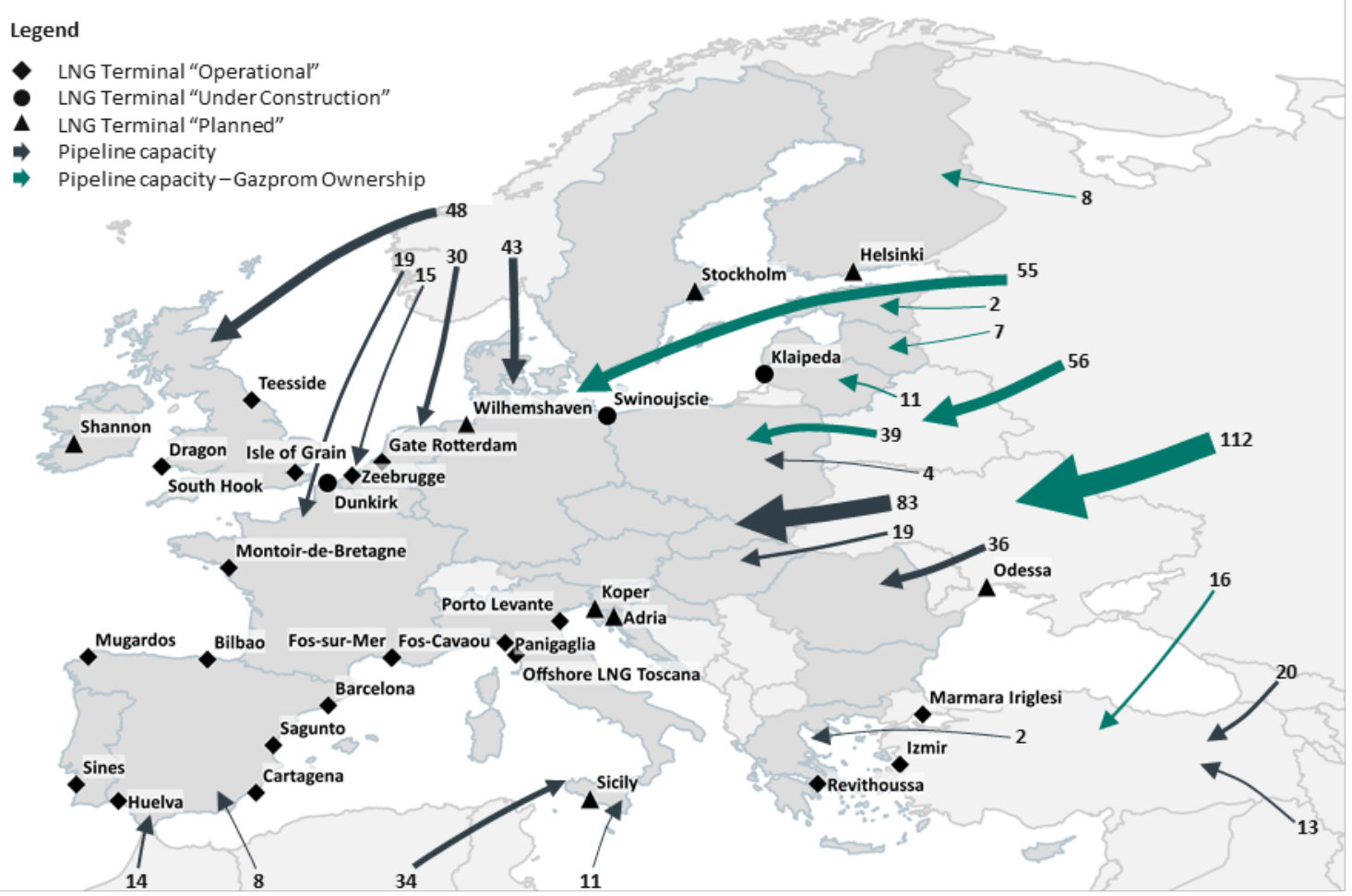

Figure 1: European LNG and pipeline import infrastructure from external suppliers in 2013.

Note: Relative arrow sizes correspond to current capacities; figures represent current capacities in bcm/a.

Source: Own illustration based on GGM database including information from GIIGNL (2013), ENTSO-G (2013a) and various sources. The blank map (shape file) has been provided by Eurostat:

http://epp.eurostat.ec.europa.eu/portal/page/portal/gisco Geographical information maps/geodata/reference, accessed on May 20, 2014. 
Table 1: LNG regasification capacity in the EU as of today, and in 2015 (GGM), in bcm.

Source: GIIGNL 2011, 2012 and 2013 and project homepages.

\begin{tabular}{|c|c|c|c|}
\hline Country & Terminal & 2013 & $\begin{array}{r}2015 \text { (GGM) } \\
\text { additions }\end{array}$ \\
\hline Belgium & Zeebrugge LNG Fluxys LNG & 9.00 & \\
\hline France & Fos Tonkin and Fos Cavaou Elengy & 8.25 & \\
\hline France & Fos-sur-Mer & 5.50 & \\
\hline France & Montoir de Bretagne Elengy & 10.00 & \\
\hline Greece & Revithousa & 5.00 & \\
\hline Italy & Panigaglia & 3.30 & \\
\hline Italy & Rovigo (Atlantic) Cavarzere Porto Levante & 8.00 & \\
\hline Italy & Offshore LNG Toscana & 3.75 & \\
\hline Lithuania & Klaipeda & - & 3.00 \\
\hline Netherlands & GATE & 12.00 & \\
\hline Poland & Swinoujscie & - & 5.00 \\
\hline Portugal & Sines REN Atlantico & 7.60 & \\
\hline Spain & Barcelona Enagas & 17.10 & \\
\hline Spain & Bilbao BBG & 7.00 & \\
\hline Spain & Cartagena & 11.80 & \\
\hline Spain & Huelva & 11.80 & \\
\hline Spain & Mugardos Reganosa FERROL & 3.60 & \\
\hline Spain & Sagunto Saggas & 8.80 & \\
\hline Spain & Gijon (El Musel); mothballed (7.5 bcm) & - & \\
\hline UK & Dragon & 6.00 & \\
\hline UK & Isle of Grain & 20.50 & \\
\hline UK & South Hook & 21.20 & \\
\hline UK & Teesside Dockside & 4.20 & \\
\hline EU & Total regasification capacity & 184 & 192 \\
\hline
\end{tabular}

\subsection{Scenario definitions}

The GGM Base Case is set up in line with projections of the New Policies Scenario (NPS) of the World Energy Outlook 2012 (IEA, 2012); a moderate climate policy scenario. ${ }^{4}$ Three disruption scenarios are constructed deviating from this Base Case. See Table 2 for detailed scenario descriptions, while Table 3 shows the capacity differences for all affected pipelines across scenarios. In order to avoid any inconsistencies, all decisions made in the first model period 2010 are held fixed at Base Case levels in all disruption scenarios. Hence, any disrup-

\footnotetext{
${ }^{4}$ See Holz et al. (2014) for an analysis of the role of natural gas under ambitious global climate policies.
} 
tion in or as of 2015 has not been anticipated by any model agent; infrastructure expansions and trade patterns for 2010 remain the same across scenarios.

The first two scenarios have been constructed around short-term disruptions of Gazprom majority-owned infrastructure. In these two disruption scenarios only the model period 2015 is shocked, i.e. affected by exogenous assumptions:

- In the first scenario, "Ukraine Disruption", it is assumed that all pipeline connections to Ukraine, which serve to deliver Russian natural gas, are interrupted. Hence, no transit via Ukraine can take place either.

- In the second scenario, "Gazprom", the total infrastructure, which is majority-owned by OAO Gazprom or any subsidiary, is interrupted. Hence, all Russian exports to Europe are cut off. Additionally, storage facilities in several European countries are affected.

Note, that these short-term shocks in only one model period are applied to a world slightly different to today, regarding production and consumption levels as well as existing infrastructure. While all current European pipeline, storage and LNG capacities are included in the data set (e.g. from ENTSO-G 2013a, GIE, 2013 and GIIGNL, 2013), some projects currently under construction are assumed to be in place in 2015, e.g the ALTAI pipeline from Russia to China with $30 \mathrm{bcm}$, or the South Stream pipeline from Russia to Bulgaria with an initial capacity of $15 \mathrm{bcm}$ in 2015. Moreover, some (small) endogenously determined infrastructure expansions between 2010 and 2015 take place in the model results.

Slack capacities for Base Case production levels in 2015 are based on country-specific assumptions. For instance, it is assumed that the slack capacities in 2015 in Norway and the Netherlands are about $10 \%$ each. At increasing cost, both countries may balance a shortfall of Russian imports to a certain extent. ${ }^{5}$

In the third scenario "Long Disruption" we assume that Russian natural gas supply to Europe is interrupted from 2015 until the end of the model horizon 2040. Similar to the Gazprom scenario, all Gazprom majority-owned infrastructures are shut down. Furthermore, we allow for unrestricted pipeline capacity expansions as of 2015 in response to the lasting disruption.

\footnotetext{
5 The regulated limitation of production at the Groningen field in the Netherlands due to concerns of seismic events is not taken into account.
} 
Hence, this scenario serves as an indicator highlighting important infrastructure projects if a Russian supply disruption is lasting and can be anticipated.

Table 2: Scenario descriptions of GGM simulation runs

Scenario Name Description Specific Assumption

\begin{tabular}{|c|c|c|}
\hline Base & $\begin{array}{l}\text { Base Case: } \\
\text { Projections of future natural gas production, } \\
\text { consumption and trade based on the New } \\
\text { Policies Scenario of the IEA (2012) }\end{array}$ & \\
\hline $\begin{array}{l}\text { Ukraine } \\
\text { Disruption }\end{array}$ & $\begin{array}{l}\text { Disruption of supply to and transit via Ukraine: } \\
\text { Interruption of Russian pipeline connection to } \\
\text { Ukraine (neither direct pipeline connection } \\
\text { from Russia nor indirect connection via Belarus } \\
\text { included) in } 2015\end{array}$ & $\begin{array}{l}\text { - Zero capacity on pipeline RUS-UKR } \\
\text { - Zero capacity on pipeline BLR-UKR }\end{array}$ \\
\hline Gazprom & $\begin{array}{l}\text { Disruption of Gazprom infrastructure to Europe } \\
\text { (incl. Turkey): } \\
\text { Reduction of total cross-country pipeline and } \\
\text { storage capacity in } 2015 \text { that is currently ma- } \\
\text { jority-owned by Gazprom (incl. subsidiaries). } \\
\text { Belarus is not affected, i.e. the pipeline from } \\
\text { Russia and the Belarussian storage capacity has } \\
\text { full capacity. However, the transit via Belarus is } \\
\text { disrupted. } \\
\text { Affected pipelines: } \\
\text { - } \quad \text { Nord Stream } \\
\text { - Brotherhood } \\
\text { - Yamal Europe } \\
\text { - Blue Stream } \\
\text { - South Stream } \\
\text { - OPAL } \\
\text { Affected storage facilities } \\
\text { - Rehden in Germany } \\
\text { - Haidach in Austria } \\
\text { - Incukalns in Latvia } \\
\text { Banatski Dvor in Serbia }\end{array}$ & $\begin{array}{l}\text { - Zero capacity on pipeline RUS-DEU } \\
\text { - Zero capacity on pipeline RUS-FIN } \\
\text { - Zero capacity on pipeline RUS-BALT } \\
\text { - Zero capacity on pipeline RUS-BGR } \\
\text { - Zero capacity on pipeline RUS-TUR } \\
\text { - Zero capacity on pipeline RUS-UKR } \\
\text { - Zero capacity on pipeline BLR-UKR } \\
\text { - Zero capacity on pipeline BLR-POL } \\
\text { - Zero capacity on pipeline BLR-BALT } \\
\text { - Reduced capacity on pipeline DEU- } \\
\text { CZE by } 74 \% \\
\text { - Reduced storage capacity in DEU by } \\
\text { - } 20 \% \\
\text { - Reduced storage capacity in AUT by } \\
\text { - Reduced storage capacity in BALT by } \\
\text { - } 100 \% \\
100 \%\end{array}$ \\
\hline $\begin{array}{l}\text { Long } \\
\text { Disruption }\end{array}$ & $\begin{array}{l}\text { Long-lasting Disruption of Gazprom infrastruc- } \\
\text { ture in Europe } \\
\text { Continuous disruption of Russian natural gas } \\
\text { supply to all EU member states and other } \\
\text { European countries (Ukraine, Serbia, Switzer- } \\
\text { land and Turkey). All Gazprom majority-owned } \\
\text { infrastructures are not used after 2010. This } \\
\text { lasting supply disruption can be anticipated } \\
\text { and responded to by investments in the pipe- } \\
\text { line network from } 2015 \text { onwards (being opera- } \\
\text { tional as of 2020). }\end{array}$ & $\begin{array}{l}\text { - } \quad \text { Similar to Gazprom but for } \\
\text { all model periods after } 2010 \\
\text { - } \quad \text { Anticipation and unlimited } \\
\text { investment as of } 2015\end{array}$ \\
\hline
\end{tabular}


Table 3: Selected pipeline (gross) capacities at the time of disruption in 2015, in bcm/a.

Note: Assumptions for the Long Disruption scenario are similar to those in Gazprom, lasting until the end of the model horizon, though.

\begin{tabular}{|llccc|}
\hline From & To & Base Case & UKR Disruption & Gazprom \\
\hline Russia & Bulgaria & 15.56 & 15.56 & 0 \\
\hline Russia & Finland & 8.36 & 8.36 & 0 \\
\hline Russia & Germany & 57.17 & 57.17 & 0 \\
\hline Russia & Turkey & 16.49 & 16.49 & 0 \\
\hline Russia & Ukraine & 114.29 & 0 & 0 \\
\hline Belarus & Baltics & 10.69 & 10.69 & 0 \\
\hline Belarus & Poland & 39.92 & 39.92 & 0 \\
\hline Belarus & Ukraine & 25.25 & 0 & 11.07 \\
\hline Germany & Czech Republic & 42.58 & 42.58 & 0 \\
\hline
\end{tabular}

\section{$3 \quad$ Results and Discussion}

\subsection{Base case projections until 2040: the setting}

The Base Case is characterized by an increasing world production and consumption over time. Notably, the Asia-Pacific region plays a dominant role both with respect to consumption and imports; the EU's import needs increase in line with its declining domestic production. In 2015, global production and consumption levels are 10\% higher than in 2010; projections for the EU see lower levels of natural gas consumption by $3 \%$, and substantially lower production levels by $18 \%$ relative to 2010 .

The EU's import dependency is projected to increase to about $90 \%$ of consumption until 2040. Imports originating from Russia increase until 2035 in levels, but decrease relative to total EU imports (see Figure 2). Base Case model results thus hint at a long-term diversification of European supplies with a higher reliance on natural gas from Africa, the Caspian region and LNG exporting countries in the next decades. 


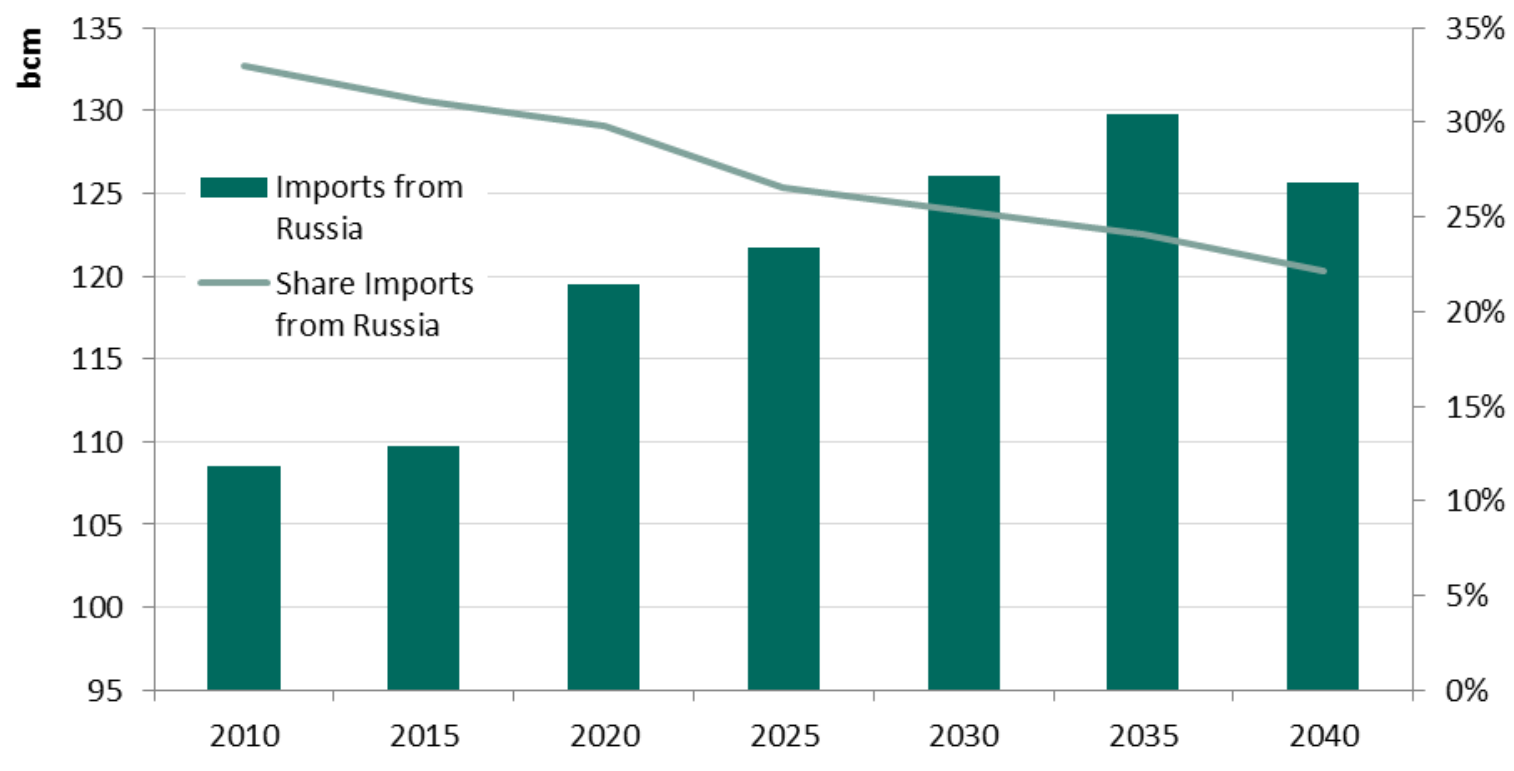

Figure 2: EU natural gas imports from Russia, in absolute values (left axis) and as share of total imports (right axis), in bcm and percentage.

\subsection{Two short-term disruption scenarios}

The two short-term scenarios are analysed and discussed relative to the described Base Case setting. All results shown in this section refer to 2015, the year of the hypothetical disruption. Of particular interest are changes in consumption levels and associated prices, as well as the EU import structure, and the role of LNG. We highlight infrastructure bottlenecks and further discuss the Russian perspective with respect to short-term export alternatives to Europe.

\subsubsection{Reduced consumption and shift in European supply structure}

As expected, in the Ukraine Disruption scenario Ukraine is substantially affected and natural gas consumption is reduced by almost 70\% in 2015 relative to the Base Case. By assumption, there is no short-term possibility to export natural gas to Ukraine via physical capacity, and domestic production can only marginally be increased.

On the other hand the EU is only slightly affected with small average reductions of consumption levels (by $2 \%$, or $11 \mathrm{bcm}$ ), although the deviation across countries is large. In particular, in Croatia, Hungary and Romania consumption is reduced substantially by more than $20 \%$ but also in Austria the Ukrainian transit disruption can be noticed (-4\% of natural gas consumption). Figure 3 depicts 2015-consumption levels relative to the Base Case. 
The Gazprom scenario is characterized by similar effects on Ukraine but a stronger impact on EU countries. At the aggregate level, EU consumption in 2015 is reduced by $10 \%$, or $53 \mathrm{bcm}$. Notable, East European countries are affected the most, but also Central European countries have lower consumption levels, like Germany with reduced consumption by $8 \%$ or $7 \mathrm{bcm}$.

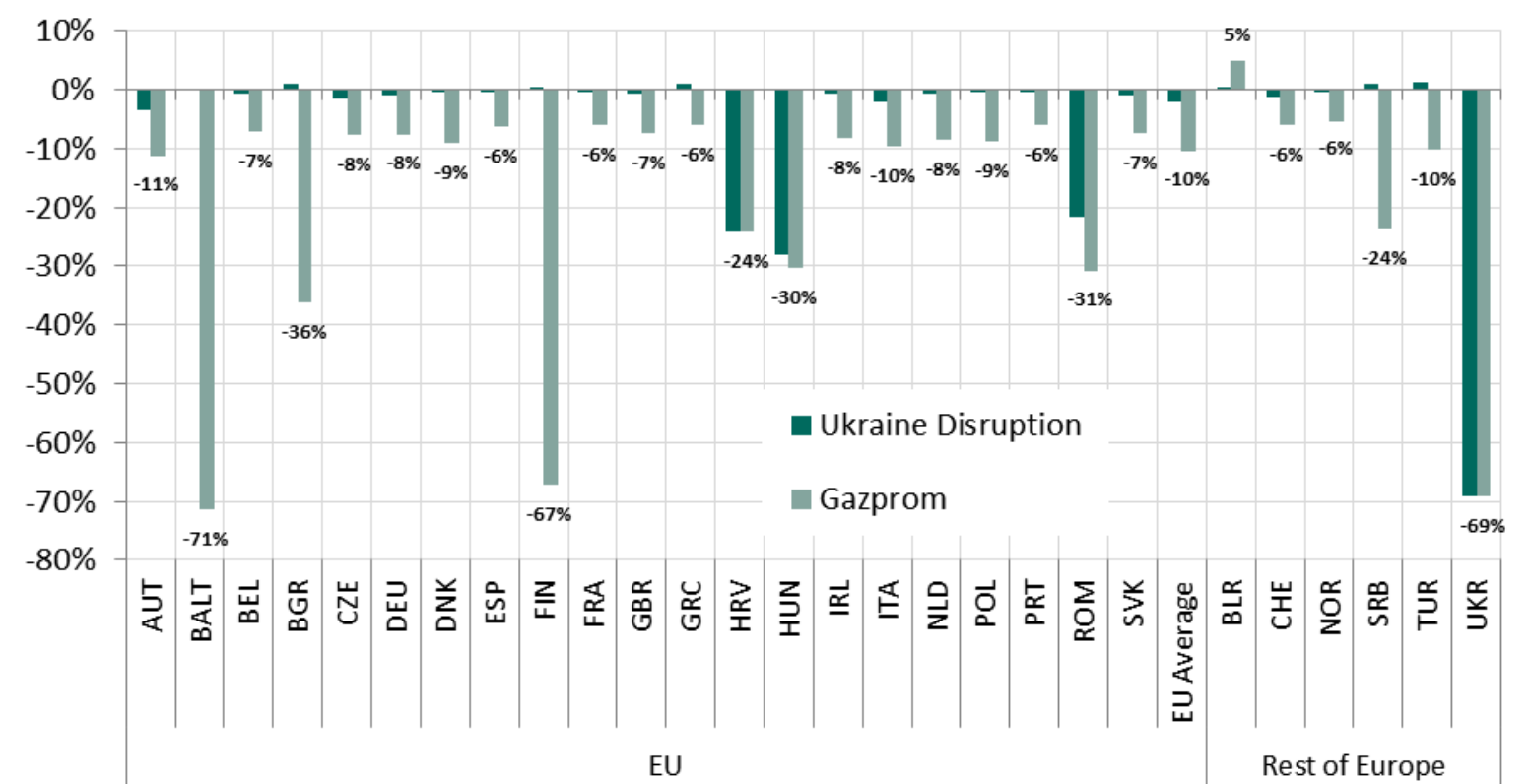

Figure 3: Changes in 2015 consumption levels relative to the Base Case, in percentages.

Note: Values for the Gazprom scenario are provided next to the respective bars.

A reduction in consumption levels can be the result both of economic considerations, i.e. the trade-off between the willingness-to-pay, and the price for natural gas and physical limitations of the available infrastructure. Accordingly, natural gas prices are changed relative to the Base Case (see Figure 4). Note, that for each country and model period, an equilibrium price-quantity pair along the constructed demand curve is reached.

Similar to consumption levels, prices in Ukraine Disruption are only significantly higher in Ukraine, Hungary, Romania and Croatia, while in Gazprom all EU countries are affected by price increases of more than $10 \%$ relative to the Base Case. For the Baltic countries the price increase is particularly pronounced in the high demand season due to the complete interruption of storage facilities. Here, prices are increased by $143 \%$ relative to the Base Case. 


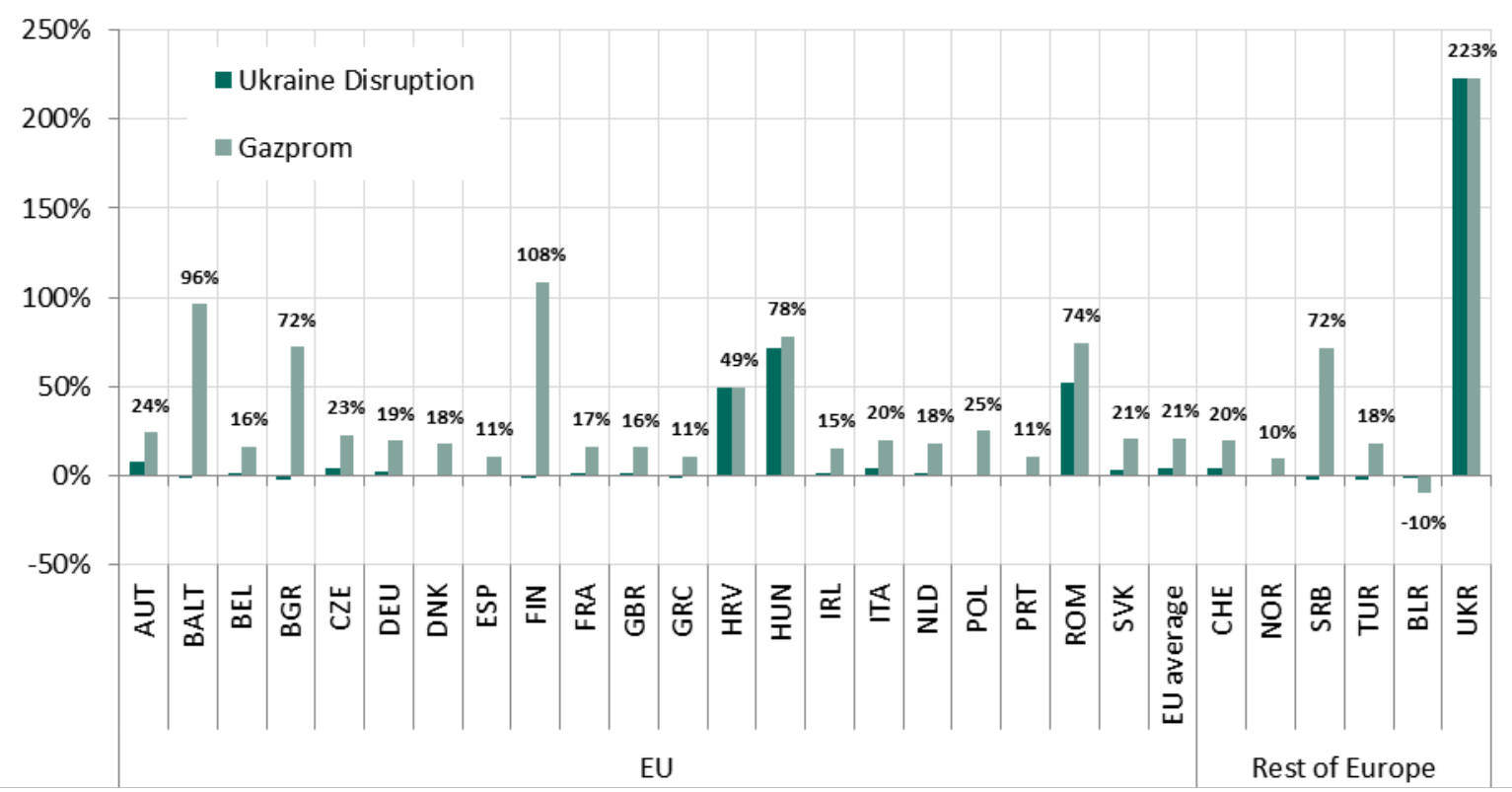

Figure 4: Prices in 2015 relative to the Base Case, in percentages.

Note: Values for the Gazprom scenario are provided next to the respective bars. For the EU, the price is calculated as consumption weighted average.

To some extent, the shortfall of Russian supply in 2015, affecting some countries (Ukraine Disruption), or all European countries (Gazprom), is compensated by an increase in domestic production as well as by imports from other producing regions. Figure 5 shows that the disruption impact is most visible in a pronounced change in the EU import structure by type of imports. In particular, the share of LNG imports is substantially increased $(+45 \mathrm{bcm}$, or almost $60 \%$ higher in Gazprom than in the Base Case), while pipeline imports drop significantly, despite small increases from North Africa and Norway. 


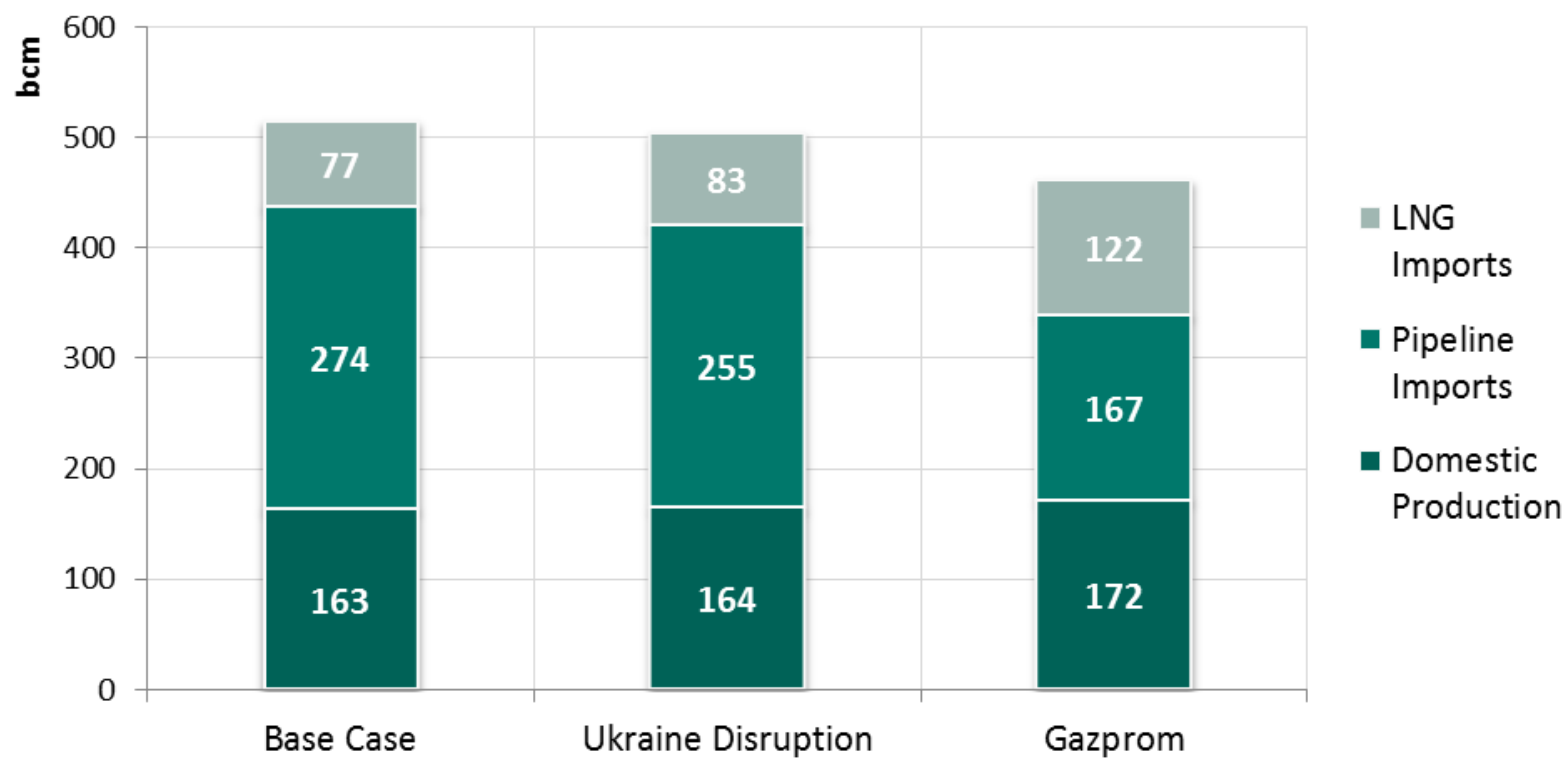

Figure 5: EU supply structure in 2015 across scenarios, in bcm.

While domestic EU production is only marginally increased in Ukraine Disruption, production is larger in the Gazprom scenario, namely by $5 \%$, or $8 \mathrm{bcm}$ relative to the Base Case. This increase is almost entirely driven by an increase in the production of the Netherlands.

In the Gazprom scenario the shortfall of $110 \mathrm{bcm}(14 \mathrm{bcm})$ imports from Russia (the Caspian region) relative to the Base Case is countervailed by the increase of $8 \mathrm{bcm}$ in domestic production and by $62 \mathrm{bcm}$ of imports from other suppliers. The remaining $53 \mathrm{bcm}$ reflect the reduction in EU consumption. As can be seen in Figure 6, natural gas is imported to a larger extent from Africa $(+18 \mathrm{bcm})$, the Middle East $(+19 \mathrm{bcm})$, South America $(+15 \mathrm{bcm})$, and the Rest of Europe (+10 bcm, mainly from Norway). 


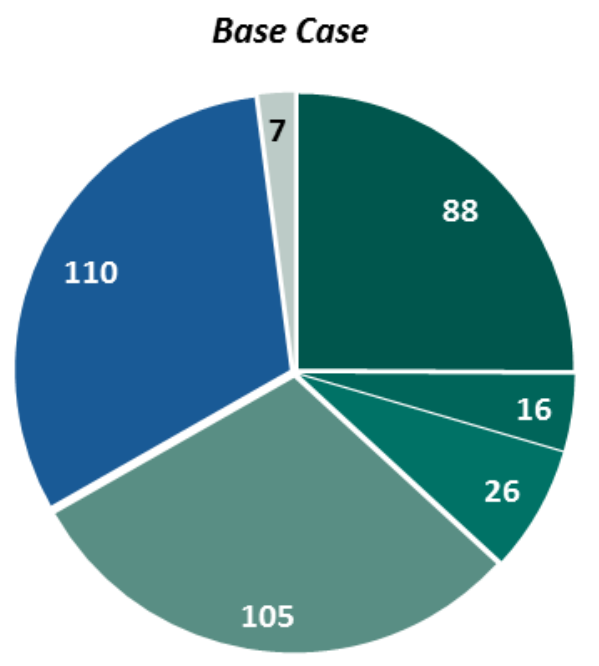

Imports: 352bcm

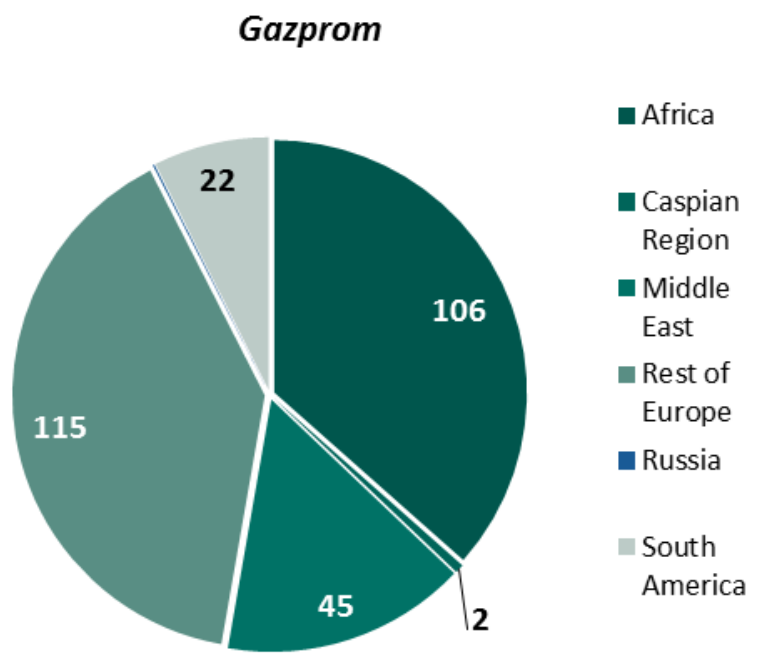

Imports: 291bcm

Figure 6: EU import structure in 2015 by supplier, in bcm.

\subsubsection{Focus on European LNG imports}

LNG imports are most important in balancing short-term Russian trade interruptions. In the Gazprom scenario the increase of LNG imports to the EU is mainly supported by Qatar, African countries like Nigeria, Algeria and Egypt, and by Trinidad \& Tobago. Figure 7 depicts the regional distribution of LNG imports into the EU and contrasts trade flows with total import capacities. The largest additional LNG imports in the Gazprom scenario relative to the Base Case can be observed in the UK, increased by a factor of 4.7 . 


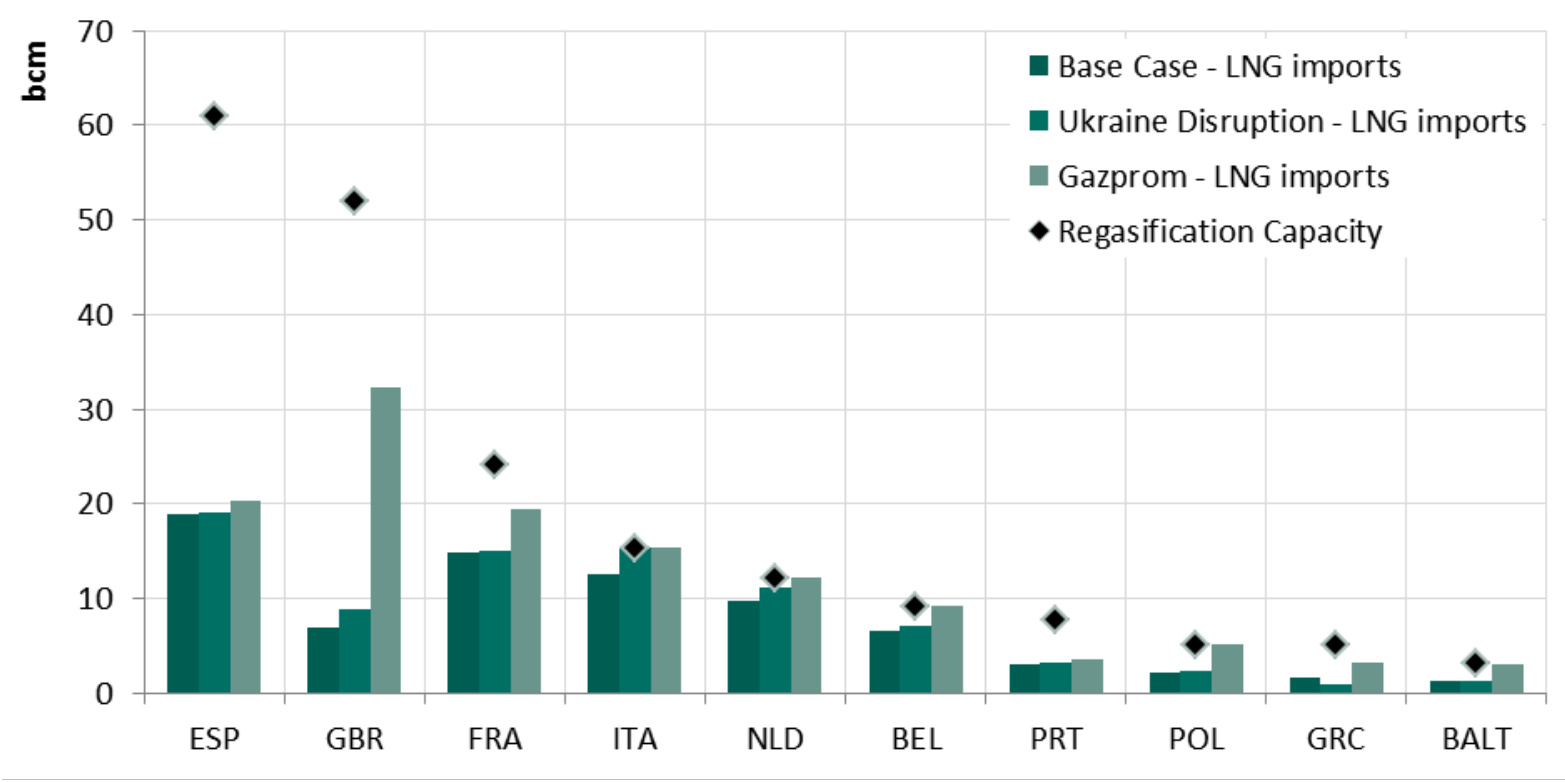

Figure 7: EU LNG imports in 2015 by countries compared to potential regasification capacity (bcm).

While regasification terminals in Italy, the Netherlands, Poland and the Baltics are completely used in the Gazprom scenario, it is deducible from Figure 7 that the utilization rate of regasification capacity in some EU countries is rather low in the two disruption scenarios.

Most remarkably, the utilization rate of Spanish terminals only reaches $33 \%$ in the Gazprom scenario, despite the need for import alternatives to Russia. Particularly, cross-border pipeline capacity restrictions prevent higher Spanish LNG imports used for an efficient distribution across Europe: The pipeline capacity from Spain to France with annual capacity of about $5 \mathrm{bcm}$ is completely utilized and cannot be extended on short notice (see Figure 8). This has also been noted by the European Council which concluded in March 2014 that "interconnections should also include the Iberian peninsula". ${ }^{6}$

Similarly, a possible increase in French LNG imports beyond the Gazprom scenario level is prevented by a lack of pipeline capacity toward Germany or Italy. Italy in turn is poorly connected to central Europe and cannot serve as transit country for African pipeline gas and LNG imports. Hence, the large total EU regasification capacity of $195 \mathrm{bcm}$ cannot be completely used to balance import needs in all member states.

\footnotetext{
${ }^{6}$ Cf. European Council 20/21 March 2014 Conclusions, p. 10: http://www.consilium.europa.eu/uedocs/cms data/docs/pressdata/en/ec/141749.pdf, accessed on May 22, 2014.
} 


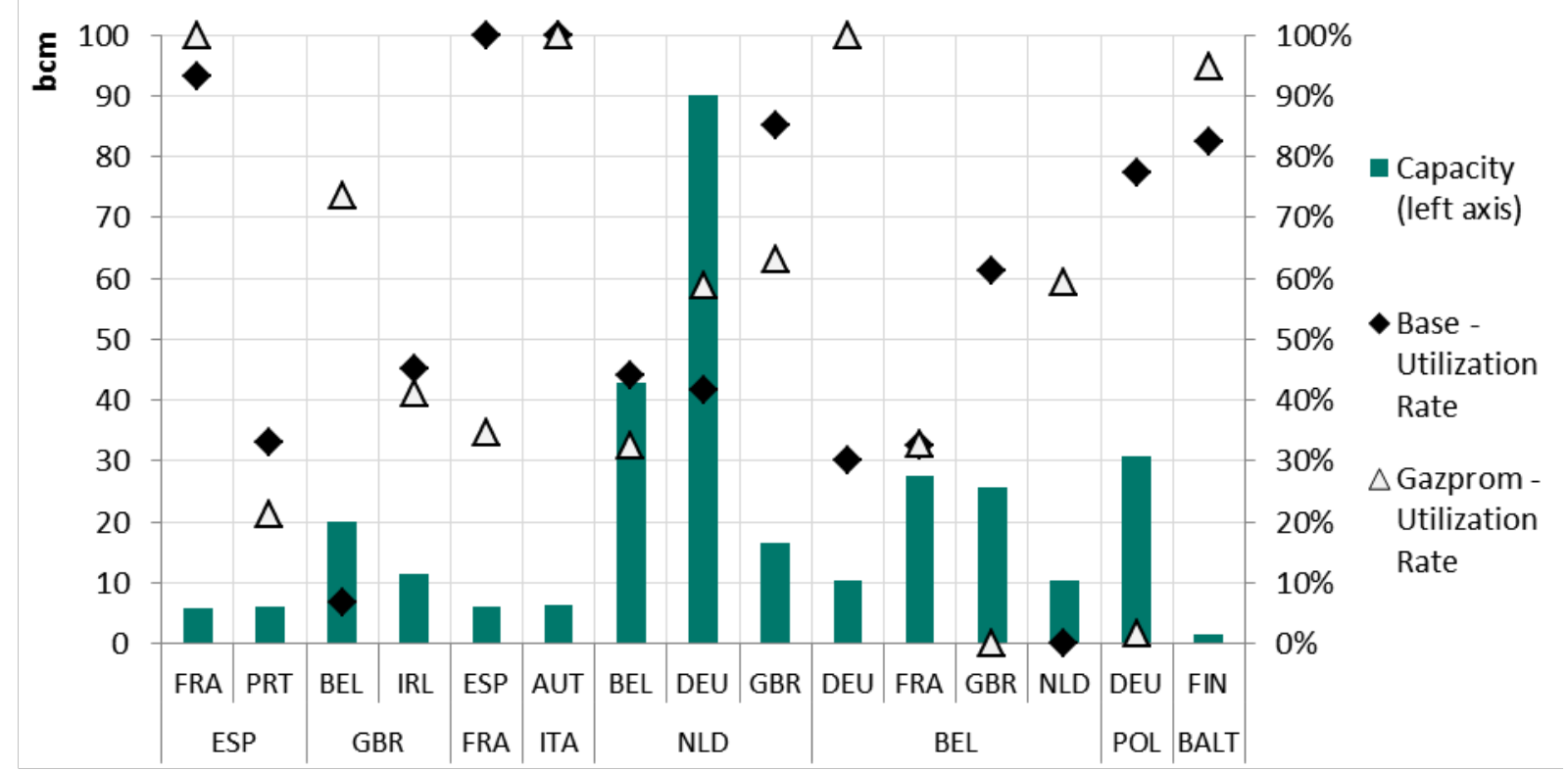

Figure 8: Pipeline capacities (left axis) and utilization rates from LNG importing countries, in bcm and percentages.

Note: The lower part of the horizontal axis is the pipeline's origin.

It should be noted that EU countries compete with other world regions for limited international LNG supply. This can be best seen in the ratio of the current worldwide annual LNG regasification capacity of around $900 \mathrm{bcm}$ to global LNG liquefaction capacity of only $360 \mathrm{bcm}$ (cf. GIIGNL, 2013). The Asia-Pacific region is and will remain the main competitor for international LNG supply to the EU. In contrast to previous expectations, the USA are expected to become a net exporter of LNG as of 2016 (cf. EIA, 2014a).

In the Gazprom scenario one can observe an increase in global LNG supply by $3.5 \%$ and a pronounced shift of LNG trade flows from Asia toward the EU. These reduced LNG flows toward Asian consumers $(-37 \mathrm{bcm})$ are partly backed by an increase in Asian pipeline imports from Russia ( $+6 \mathrm{bcm}$ relative to the Base Case) and the Caspian region ( $+23 \mathrm{bcm}$ ).

\subsubsection{Changes in the Russian supply of natural gas}

In both disruption scenarios, one can observe the following pattern for Russia: exports are lower than in the Base Case (by 16\% in Ukraine Disruption, and 30\% in Gazprom), domestic consumption increases, but to a lower extent (by $3 \%$, and $14 \%$ respectively), such that overall production is reduced (by $2 \%$, and $10 \%$ respectively).

This is explained by the limited export possibilities of Russia with available capacities in 2015. The (East) Russian LNG export terminal in Sakhalin is completely utilized in the Base Case already, and an increase of LNG exports is no alternative to the shortfall in exports toward 
Europe; pipeline exports toward Asia, on the other hand, are limited by capacity and compete with exports from the Caspian region.

Hence, one can observe a shift in the destination of Russian natural gas toward domestic consumption due to a lack of export alternatives as illustrated in Figure 9. This, of course, means a substantial reduction of revenue, both for Gazprom and for Russia (in form of profit, mineral extraction and export tax income).

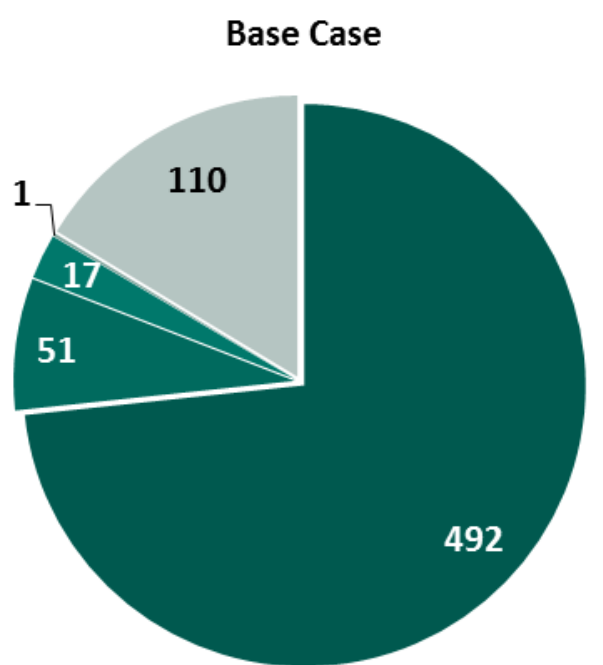

Supply: $671 \mathrm{bcm}$

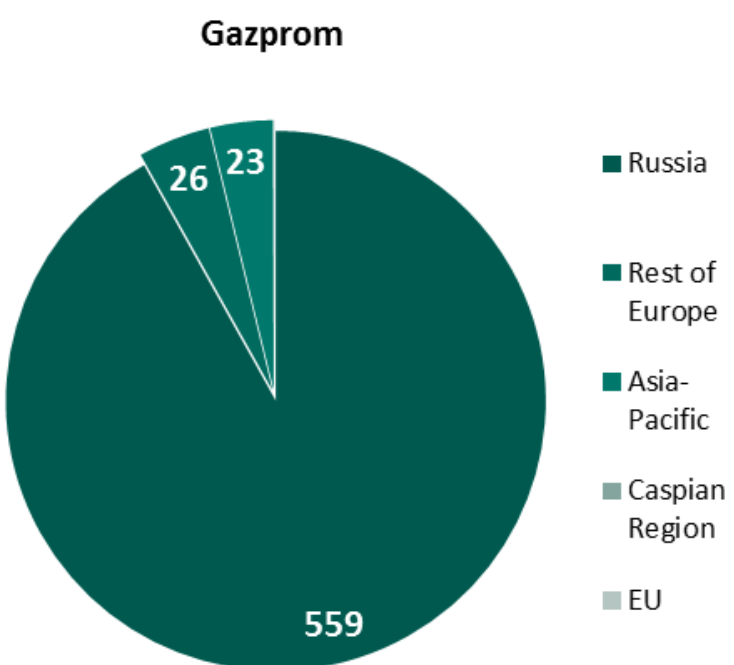

Supply: $608 \mathrm{bcm}$

Figure 9: Consumption of Russian natural gas by region in 2015 , in bcm.

A similar pattern arises for the Caspian region, which is limited in the short-term in its export possibilities toward Europe via the Russian transit. Production is lower in the disruption scenarios in 2015 relative to the Base Case, while consumption increases. All other world regions are also affected somewhat, in order to cope with the shift in natural gas flows and the reduced supply of Russian natural gas on the world market. Exports are increased at the expense of domestic consumption (e.g. in Africa, where consumption is reduced by $9 \%$ in the Gazprom scenario). Global production patterns show a significant relative increase in Africa, the EU and Rest of Europe to partly balance the reduced production in Russia and the Caspian region. 


\subsection{Long-term disruption scenario}

In case of an anticipated or long-lasting disruption of Russian natural gas exports, adjustments can be made by expanding the existing transportation infrastructure. Investment costs are weighted by the TSO against the future stream of revenues from pipeline transit fees. Both intensified connections to external suppliers and expansions of the intraEuropean pipeline network serve to attenuate the disruption of Russian natural supply.

\subsubsection{Impact of a long-term disruption}

Figure 10 shows aggregate consumption levels of the EU, as well as consumption weighted prices for the Base Case and Long Disruption. The divergence between both cases is particularly pronounced in the initial period of the external shock: In 2015 , consumption is $10 \%$ lower in Long Disruption (53 bcm), while the consumption weighted average price is more than $20 \%$ higher. These differences diminish already in 2020 to $5 \%$ lower consumption levels at $4 \%$ higher prices on average. Overtime both the consumption and price paths tend to converge to a gap of, respectively, $4 \%$ and $8 \%$ between the two scenarios.

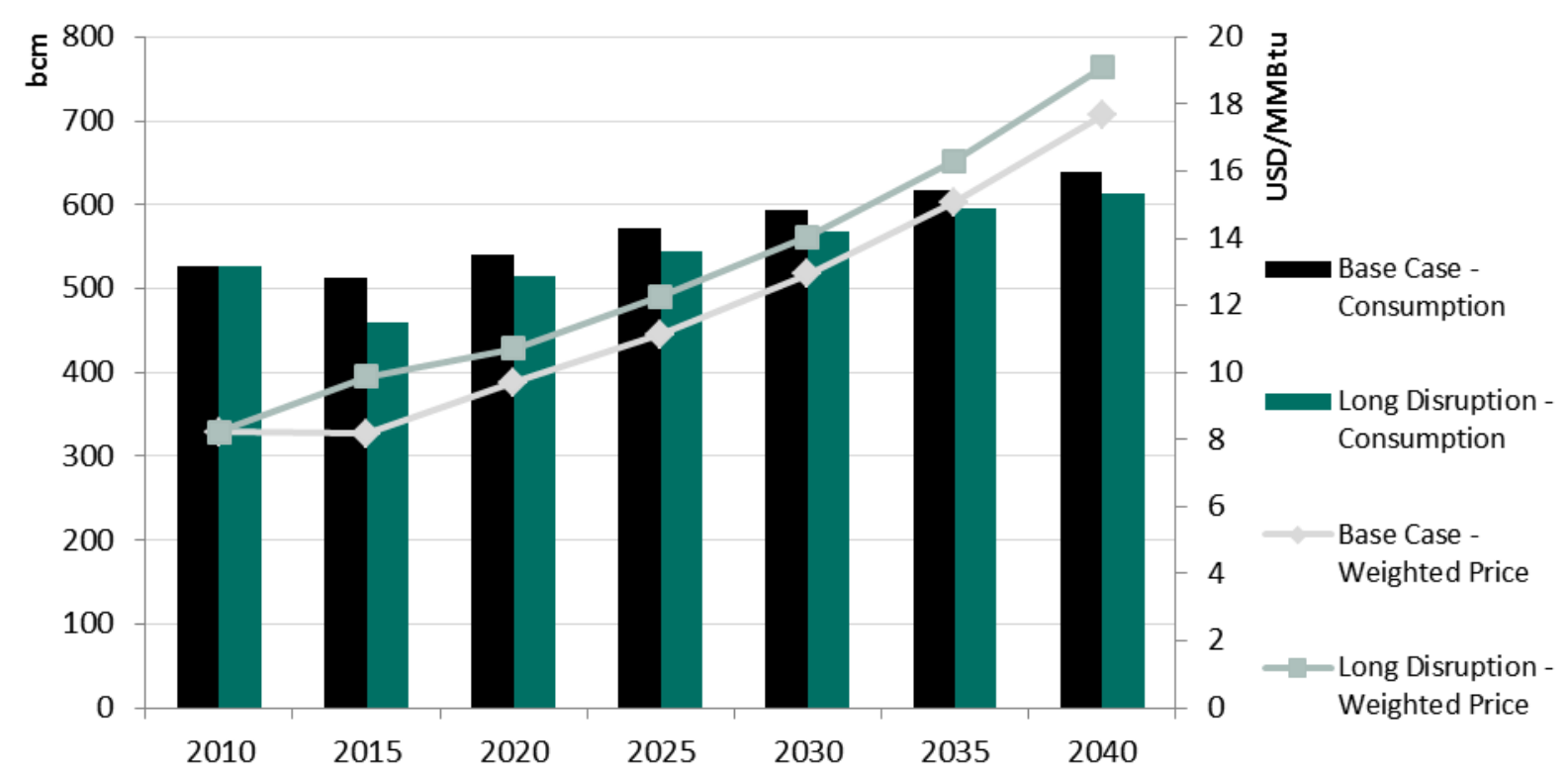

Figure 10: Natural gas consumption (left axis) and weighted prices (right axis) in the EU over time and across scenarios, in bcm and USD/MMBtu.

Compared to the Gazprom scenario, one can observe an increased balancing within the EU, such that only the Baltics and Finland are considerably affected after 2020: Despite adjustment possibilities of the infrastructure, natural gas consumption is lower at significantly 
higher prices than in the Base Case, which are about 20\% higher in Finland and more than 30\% higher in the Baltics after 2020.

As in the short-term disruption scenarios, LNG imports are most important in balancing the drop out of Russian supply. While they account for about a quarter of total imports throughout in the Base Case, LNG imports reach almost $40 \%$ in Long Disruption over time. They originate from Africa, the Middle East and South America (see Figure 11). Notably, in later periods after 2025, the USA become an additional supplier of LNG to the EU, with annual volumes of more than $30 \mathrm{bcm}$. By contrast, in the Base Case US LNG exports to Europe only occur in the final model period, though at significantly lower volumes below $10 \mathrm{bcm}$ in 2040 . Compared to EIA (2014a) projections of total US LNG exports of $100 \mathrm{bcm}$ as of 2030, these flows are rather small. The Middle East in turn increasingly relies on pipeline exports via Turkey to Europe and via Pakistan to India. LNG exports to Europe are consequently declining over time in both scenarios.

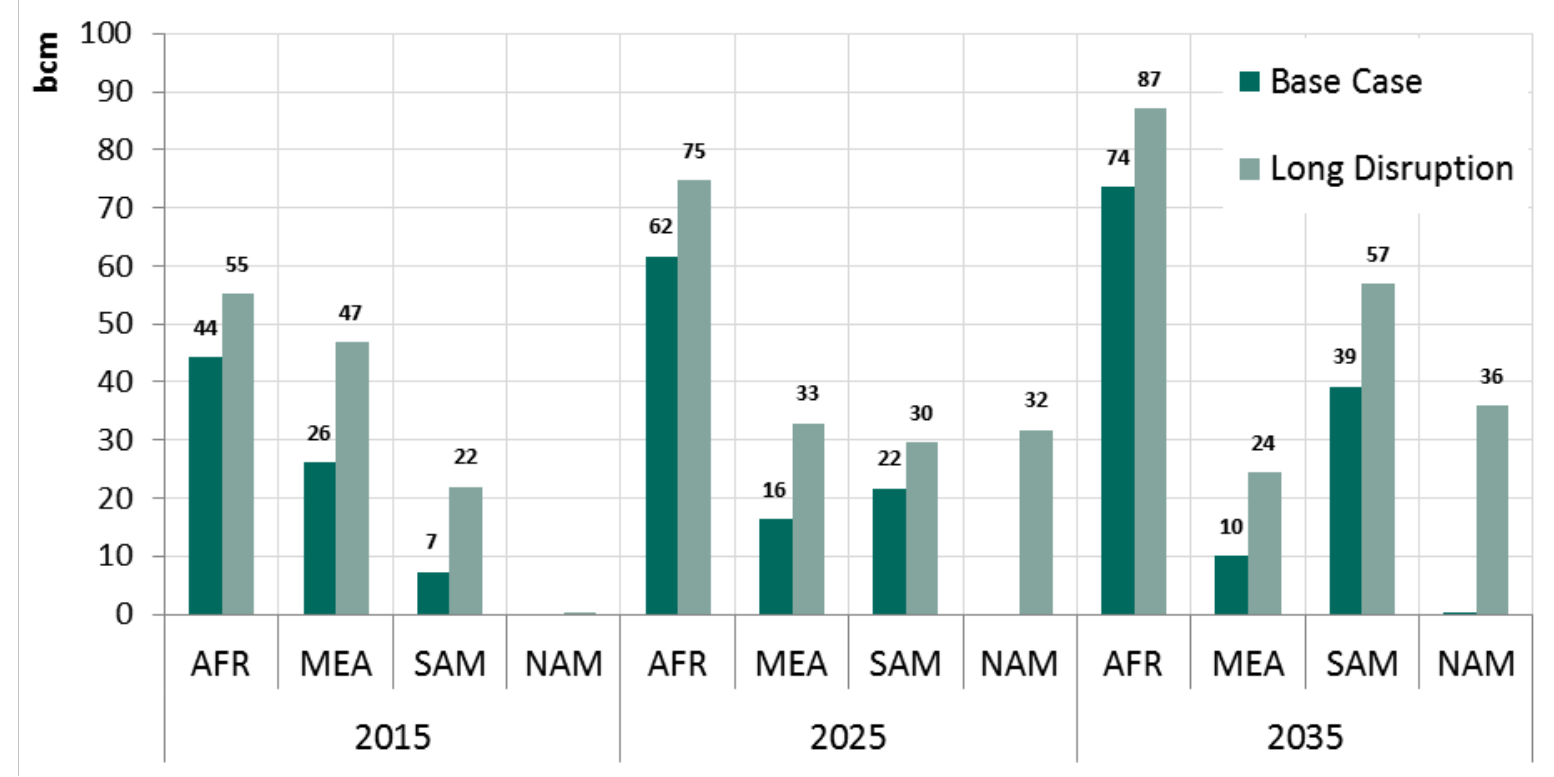

Figure 11: LNG imports to the EU by destination region, in bcm.

Total imports to the EU (LNG plus pipeline imports) are dominated by African suppliers. Exports from the Middle East serve to replace Russian supply in South East Europe, namely Turkey, Bulgaria, Romania and Ukraine, while the Caspian region is more focused on Asian consumers; not least since the transit route via the Ukraine has to be replaced. 


\subsubsection{Infrastructure expansions}

In order to connect the Middle East and reconnect the Caspian region to Europe substantial pipeline expansions in the Southern corridor are needed. Figure 12 depicts expansions of the European import infrastructure in 2015 , i.e. in the first model period of the lasting disruption of Russian supply. In the Long Disruption scenario the pipeline routes from the Middle East and the Caspian region to Europe via Turkey dominate all other expansions from external suppliers like North African countries or Norway. From Turkey the connection to Bulgaria is expanded to a larger extent than with destination to Greece. Expansions in the Base Case are significantly lower in this model period.

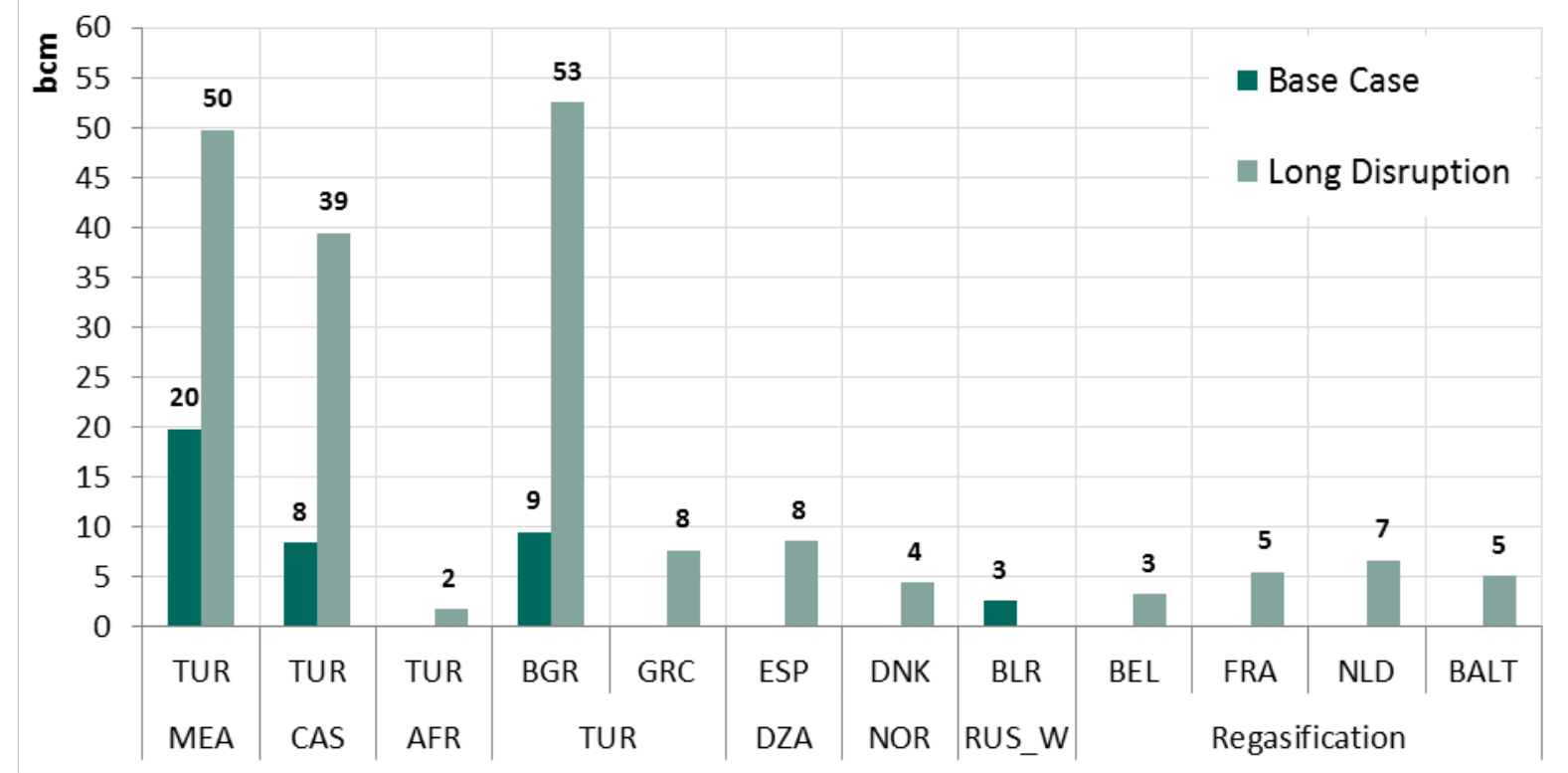

Figure 12: Expansions of import infrastructure to Europe in 2015 in the Base Case and Long Disruption, in bcm.

Note: The lower part of the horizontal axis is the pipeline's origin, or classifies location of regasification terminals.

In addition, the inner-European pipeline network is expanded in four principal geographical regions. This is illustrated in Figure 13 by cumulative expansions until 2040 in Long Disruption and the Base Case. First, the connection of Western Europe LNG import capacity from Spain to France and further to Central Europe is expanded. This bottleneck, as discussed above and shown in Figure 8, warrants the necessary investment costs. Second, the Italian import potential is connected to the North to a larger extent. LNG imports, natural gas from North Africa, as well as imports from the Caspian Region and the Middle East through the 
TAP pipeline via Greece are all going through Italy. Third, the energy island formed by the Baltics and Finland is better connected to Poland.

Finally, South East Europe sees investments in both reverse flows, and in import capacity from the Middle East (i.a. Iran) and the Caspian region. Such an import pipeline in the Southern Corridor would be similar to the earlier Nabucco project that was abandoned in 2013 because of lack of contracted supplies and competition from the South Stream pipeline from Russia. In the absence of Russian supplies, the Southern Corridor connection from Bulgaria to Serbia and Romania and further to Hungary and Ukraine is expanded to transport natural gas to those countries which are most affected from a Russian supply disruption. Hungary plays an important role both for the pipeline routes from North to South and vice versa. Most notably, while many pipelines are expanded in the Base Case to a similar extent, the Southern Corridor pipeline is only invested in when Russian supplies are disrupted in the long term.

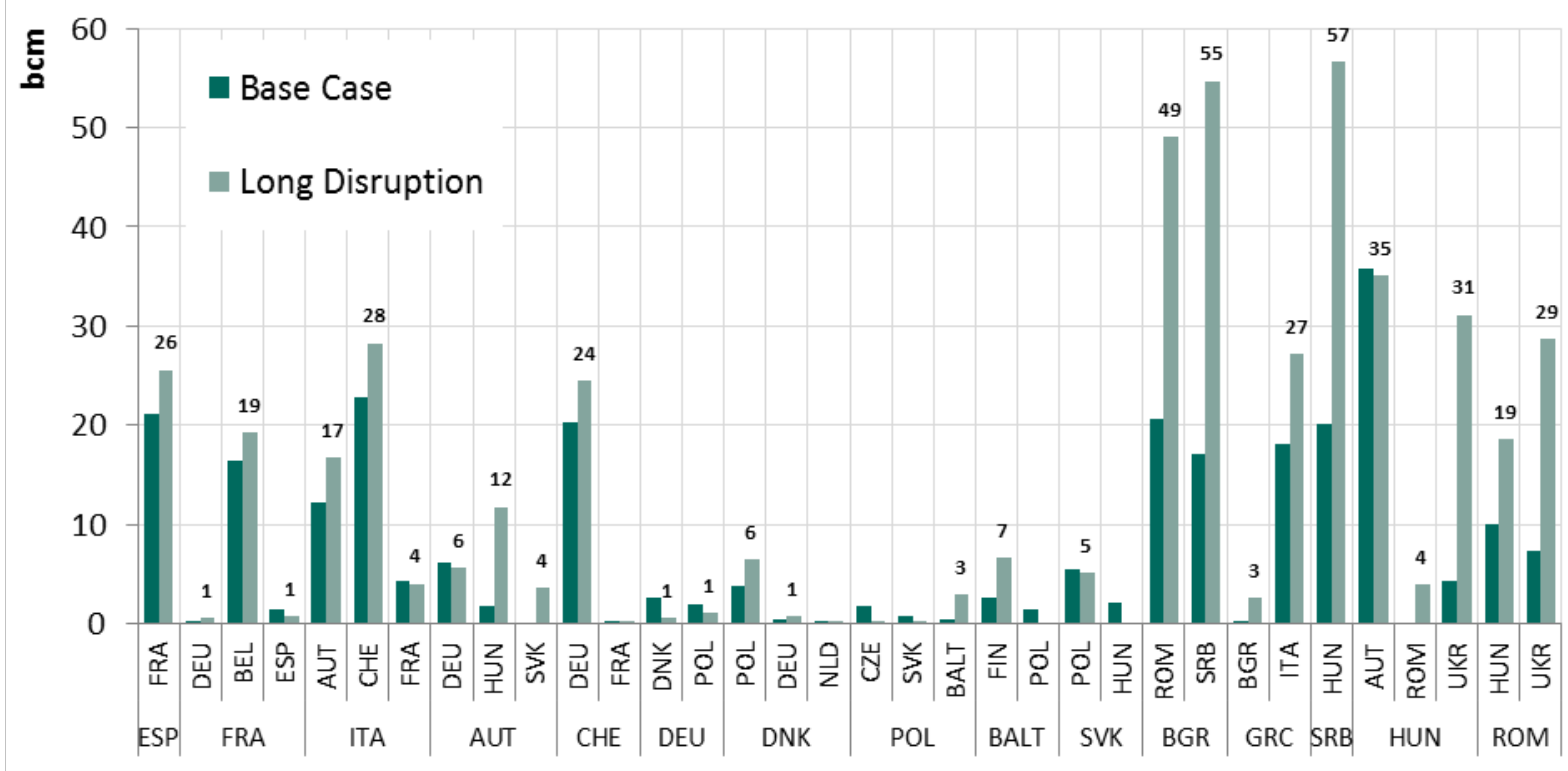

Figure 13: Cumulative intra-European pipeline expansions until 2040, in bcm. Note: The lower part of the horizontal axis is the pipeline's origin.

\section{$4 \quad$ Conclusions and Policy Implications}

The Russian-Ukrainian crisis of 2014 has revitalized the European concerns of supply disruptions of natural gas as experienced in 2006 and 2009. Despite being better prepared to Russian export disruptions today - due to more diversified imports, a better connection within 
Europe and a common EU regulation on the security of supply - several East European countries are highly dependent on Russian natural gas.

We use a model-based approach to analyse the consequences of supply disruptions of Russian natural gas on the European market. Short-term disruptions of Russian exports to Europe without anticipation severely affect several countries in East Europe due to insufficient physical capacities to be supplied by other exporting regions. In the complete drop out of Russian supply, cuts of imports from Russia can be compensated by an increase in domestic production, imports of LNG and pipeline gas from other regions, and by a reduction of natural gas consumption. Only East European countries are restricted physically, while on average the EU member states experience price increase of about $20 \%$ in the first year of the disruption.

We find a vital role of LNG imports in replacing Russian pipeline gas, although a large part of the European LNG import capacity is not well connected to a broader market. Despite strong price increases and lower natural gas supplies in the Baltics, Finland and other East European countries, Spanish regasification capacity is only partially used.

A long-lasting or early anticipated disruption of Russian supply can be mitigated by targeted pipeline expansions. We identify several geographical corridors where pipeline expansions help to ensure the secure supply of natural gas in case of a drop out of Russian supplies: first, the Iberian peninsula and Italy must be connected to the rest of Europe in order to open up their large import potential from diverse suppliers to the rest of Europe. Second, the Baltics and Finland must be connected to the rest of Europe, in particular via Poland. Similarly, reverse flow capacities must be expanded to supply the most affected East European countries in case of a disruption. And finally, the Southern Corridor will allow for imports from the Caspian region and the Middle East.

The reduction of natural gas consumption is partly compensated by the use of other energy carriers. This change in the energy mix should be in accordance with climate mitigation targets and not involve the dirtier fossil fuels coal and oil. Rather, the increased deployment of renewable energies and the intensified improvement of energy efficiency represent the sustainable complement to secure natural gas supplies. 


\section{References}

Behrens, Arno and Julian Wieczorkiewicz, 2014. Is Europe vulnerable to Russian gas cuts?. CEPS Commentary March 2014.

EU (European Union). 2010. Regulation No 994/2010 of the European Parliament and of the Council of 20 October 2010 concerning measures to safeguard security of gas supply.

Egging, Ruud, Steven A. Gabriel, Franziska Holz, and Jifang Zhuang, 2008. A Complementarity Model for the European Natural Gas Market. Energy Policy 36 (7): 2385-414.

Egging, Ruud, 2013. Benders decomposition for multi-stage stochastic mixed complementarity problems - Applied to a global natural gas market model. European Journal of Operational Research no. 226: 341-353.

EIA (Energy Information Administration), 2014a. Annual Energy Outlook 2014. EIA, US Department of Energy. Washington, DC.

EIA (2014b). US Natural Gas Data. http://www.eia.gov/naturalgas/data.cfm. Accessed on May 10, 2014. EIA, US Department of Energy. Washington, DC.

ENTSO-G (European Network of Transmissions System Operators for Gas), 2013a. The European Natural Gas Network (Capacities at Cross-Border Points on the Primary Market). Brussels, July 2013a.

ENTSO-G, 2013b. Ten-Year Network Development Plan 2013-2022, Main Report. Brussels.

Facchinei, Francisco and Jong-Shi Pang, 2003. Finite-Dimensional Variational Inequalities and Complementarity Problems. Vol. 1 and 2, Springer, New York.

Ferris, Michael C. and Todd S. Munson, 2000. "Complementarity Problems in GAMS and the PATH Solver." Journal of Economic Dynamics and Control no. 24 (2): 165-188.

GIIGNL (International Group of LNG Importers), Various years. The LNG Industry. http://www.giignl.org/fr/home-page/Ing-industry/ Paris.

GIE (Gas Infrastructure Europe), 2011. GSE Storage Map. August 2011.

GIE, 2013. GSE Storage Map. July 2013.

Hayashi, Masatsugu, and Larry Hughes, 2013. The Policy Responses to the Fukushima Nuclear Accident and Their Effect on Japanese Energy Security. Energy Policy 59: 86-101. 
Hirschhausen, Christian von, Berit Meinhart, and Ferdinand Pavel, 2005: Transporting Russian to Europe - A Simulation Analysis. The Energy Journal 26 (2): 49-68.

Holz, Franziska, 2007. How Dominant is Russia on the European Natural Gas Market? Results from Modeling Exercises. Applied Economics Quarterly, Supplement, Vol. 53 (58), pp.85-101.

Holz, Franziska, Philipp M. Richter, and Ruud Egging, 2013. The Role of Natural Gas in a LowCarbon Europe: Infrastructure and Regional Supply Security in the Global Gas Model. DIW Discussion Paper 1273. Berlin.

Holz, Franziska, Philipp M. Richter, and Ruud Egging, 2014. The Future of Natural Gas in a Global Perspective: Resources, Trade, and Climate Constraints. Mimeo. Berlin.

Hubert, Franz and Svetlana Ikonnikova, 2011. Investment Options and Bargaining Power in the Eurasian Supply Chain for Natural Gas. The Journal of Industrial Economics 59 (1): $85-116$.

Huppmann, Daniel, Ruud Egging, Franziska Holz, Christian von Hirschhausen and Sophia Rüster, 2011. The world gas market in 2030 - development scenarios using the World Gas Model. International Journal of Global Energy Issues 35 (1): 64-84.

IEA (International Energy Agency), 2012. World Energy Outlook 2012. OECD/IEA, Paris.

IEA, 2013. Natural Gas Information Statistics Database. OECD/IEA, Paris.

IEA, 2014. Facts in Brief: Russia, Ukraine, Europe, Oil \& Gas. OECD/IEA, Paris.

Lochner, Stefan, 2011. Modeling the European Natural Gas Market During the 2009 RussianUkrainian Gas Conflict: Ex-Post Simulation and Analysis. Journal of Natural Gas Science and Engineering 3 (1): 341-48.

Lochner, Stefan, and Caroline Dieckhöner, 2012. Civil Unrest in North Africa-Risks for natural gas supply? Energy Policy 45: 167-75.

Paltsev, Sergey, 2014. Scenarios for Russia's Natural Gas Exports to 2050. Energy Economics 42: 262-270.

Richter, Philipp M., 2013. From Boom to Bust? A Critical Look at US Shale Gas Projections. DIW Discussion Paper 1338. Berlin. 